\title{
SOSIOANTROPOLOGI GIZI DAN KESEHATAN
}

Pengaruh Budaya Terhadap Pangan, Sistem Budaya Terhadap Makanan, Masalah Budaya

Dan Makanan Terhadap Gizi, Serta Solusi Mengatasi Masalah Budaya Dan Makanan

Terhadap Gizi Dan Kesehatan

\section{Safra Al Munawwirah}

70200121037

\section{Universitas Islam Negeri Alauddin Makassar}

\section{PEMBAHASAN:}

\section{A. PENGARUH BUDAYA TERHADAP PANGAN}

Pangan pokok, merupakan kebutuhan pokok dasar manusia yang dalam pemenuhannya menghadapi tantangan cukup besar, yaitu pertambahan jumlah penduduk yang pesat, ketergantungan pada beras sebagai sumber karbohidrat, dan tingginya alih fungsi lahan. Adapun pengaruh budaya terhadap pangan diantaranya:

- Adanya bermacam jenis makanan dari setiap komunitas masyarakat. Misalnya sagu: Dalam pengolaan makanan seperti sagu pasti berbeda-beda dalam setiap daerah, sehigga kandungan dalam makanan berbahan pokok sagu tentunya pasti berbeda pula karena diolah dengan campuran bahan makanan lainnya. Dan tentunya pasti pengolaannya sesuai ciri khas daerah masing-masing. Misalnya bagian Padang cita rasanya pedis, Jawa cita rasanya manis, Dan bagian Timur cita rasanya asin.

- Adanya kebiasaan makanan dalam setiap rumah tangga Kebiasaan makan merupakan cara bagaimana rumah tangga memilih pangan dan mengonsumsinya sebagai reaksi terhadap pengaruh berbagai faktor, di antaranya adalah faktor psikologis, lingkungan, kondisi sosial ekonomi, ketersediaan dan akses terhadap sumber pangan lokal, budaya masyarakat setempat, dan penyuluhan melalui program-program terkait konsumsi pangan.

\section{B. SISTEM BUDAYATERHADAP MAKANAN}

- Memberikan peranan terhadap nialai makanan

- Berdasarkan sifat makanan ( Boleh dan tidak boleh dimakan) Berbagai sistem budaya memberikan peranan dan nilai yang berbeda-beda terhadap makanan, misalnya bahan-bahan makanan tertentu oleh suatu budaya masyarakat dapat dianggap tabu atau bersifat pantangan untuk dikonsumsi karena 
alasan sakral tertentu atau sistim budaya yang terkait didalamnya. Disamping itu ada jenis makanan tertentu yang di nilai dari segi ekonomi maupun sosial sangat tinggi eksistensinya tetapi karena mempunyai peranan yang penting dalam hidangan makanan pada sesuatu perayaan yang berkaitan dengan kepercayaan masyarakat tertentu maka hidangan makanan itu tidak diperbolehkan untuk dikonsumsinya bagi golongan masyarakat tersebut. Seperti daun kelor, masyarakat sebagian beranggapan bahwa daun kelor tidak baik untuk Ibu hamil sehingga tidak boleh memakannya, akan tetapi kita ketahui bahwa daun kelor mengandung banyak zat gizi yang baik untuk ibu hamil, misalnya memperkuat daya tahan tubuh, mencegah anemia, serta mendukung perkembangan organ janin. Namun itu bertolak belakang dengan pemikiran masyarakat karena pengaruh dari budaya yang turun temurun mempercayai bahwa daun kelor tidak baik untuk Ibu hamil.

- Berdasarkan hidangan makanan

Makanan sebagai bagian dari budaya, sangat erat kaitannya dengan bagaimana makanan itu disiapkan untuk lebih "baik" dengan keterbatasan sumber daya alam sekitar. Artian baik disini adalah yang sesuai dengan nilai-nilai agama (kepercayaan), adat, sejarah, dan lingkungan. Misalnya mengonsumsi makanan dalam keluarga, tidak boleh mulai makan saat kepala keluarga sang ayah belum makan terlebih dauhu atau tamu. Sehingga nilai gizi tentunya sudah berkurang bagi orang-orang yang terakhir makan.

- Gaya hidup budaya perkotaan dengan tingkat kesibukan yang tinggi akibat pekerjaan. Contohnya; pada ibu-ibu di daerah perkotaan yang kurang dan tidak sering menyusui bayinya dengan Air Susu Ibu (ASI) setelah melahirkan tetapi hanya diberikan formula susu bayi instant. Padahal kita tahu bahwa ASI sangat penting untuk pertumbuhan dan perkembangan fisik bayi. Selanjutnya gaya hidup mereka yang berasal dari golongan ekonomi atas (masyarakat elite kota), dalam hal makanan sering mengkonsumsi makanan yang berasal dari produk luar negeri atau makanan instant lainnya karena soal "gengsi".

\section{MASALAH BUDAYA DAN MAKANAN TERHADAP GIZI}

Mencermati akan adanya budaya, kebiasaan dan sistem sosial masyarakat terhadap makanan seperti pola makan, tabu atau pantangan, gaya hidup, gengsi dalam mengkonsumsi jenis bahan makanan tertentu, ataupun prestise dari bahan makanan tersebut yang sering terjadi di kalangan masyarakat apabila keadaan tersebut berlangsung lama dan mereka juga belum memahami secara baik tentang pentingnya faktor gizi dalam mengkonsumsi makanan maka tidak mungkin dapat berakibat timbulnya masalah gizi atau gizi salah (Malnutrition). Adapun masalahmasalah budaya dan makanan terhadap gizi, diantaranya:

1. Masalah gizi bagi orang yang rentan, misalnya Ibu hamil/ menyusui/ manula/ bayi. Pada balita masih ada ibu yang memberikan makanan pendamping ASI 
(MP-ASI) sebelum umur 6 bulan yang menyebabkan stunting pada bayi akibat kekurangan gizi. ASI eksklusif dapat mempengaruhi kejadian stunting karena jika bayi yang belum cukup umur 6 bulan sudah diberi makanan selain ASI akan menyebabkan usus bayi tidak mampu mencerna makanan dan bayi akan mudah terkena penyakit karena kurangya asupan. Sehingga balita yang sering menderita penyakit infeksi akan menyebabkan pertumubuhannya terhambat dan tidak dapat mencapai pertumbuhan yang optimal.

2. Keadaan sakit karena adanya kekurangan dan kelebihan gizi/nutrisi salah. Jika seseorang mengalami kekurangan gizi maka kondisi tersebut akibat dari konsumsi makanan yang tidak memadai jumlahnya pada kurun waktu cukup lama. Contoh : Kekurangan Energi Protein (KEP) dapat menyebabkan penyakit marasmus dan kwashiorkor. Namun jika seseorang mengalami kelebihan Gizi (Overnutrition), keadaan ini diakibatkan oleh konsumsi makanan yang berlebihan untuk jangka waktu yang cukup lama sebagai contoh: kegemukan. Tentunya faktorfaktor tersebut tidak terlepas dari pengaruh budaya masyarakat.

3. Kebiasaan dan pola yang berdampak pada masalah gizi.

Masih terdapat beberapa orang tua yang tidak memberikan/dipantangkan makanan tertentu kepda anaknya yang diakibatkan dari kebiasaana atau pola perilaku Ibu dari dulu. Jenis makanan yang paling banyak di pantangkan kepada anak adalah daging dan sayur, dimana diketahui bhwa daging memiliki kandungan gizi protein yang tinggi. Namun beberapa jenis makan yang dipantangkan kepada anak tersebut dikarenakan alasan kesehatan seperti gatal-gatal, sehingga orang tua tidak membrikan makanan tersebut walaupun mempunyai nilai gizi yang tinggi dan dibutuhkan oleh anak dalam proses tumbuh kembangnya. Oleh karena itu orang tua harus mencari opsi atau makanan lain yang memiliki nilai gizi yang setara sehingga mampu mencegah anak mengalami stunting.

\section{SOLUSI MENGATASI MASALAH BUDAYA DAN MAKANAN TERHADAP GIZI DAN KESEHATAN}

Masalah budaya dan makanan kita ketahui dapat menyebabkan masalah gizi yang berdampak pada kesehatan tubuh manusia, sehingga perlu secara cermat memberdayakan masyarakat lokal melalui perbankan struktur sosialmasyarakat melalui pandangan mereka. Langkah-langkah yang ditempuh seperti:

- Perbaikan gizi keluarga dengan melakukan lomba menyiapkan hidangan makanan non beras (kasus budaya Timor),

- Perbaikan budaya masyarakat dengan pengaruh utama gender terutama di tingkat keluarga.

- Memperluas areal pertanian dengan menanam berbagai komoditi yang mempunyai nilai gizi tinggi sebagai bahan pangan/makanan seperti kedelai (kasus budaya Jawa).

- Pemberian makanan tambahan yang bernilai gizi bagi anak-anak balita dan orang lanjut usia.

- Penyuluhan gizi terpadu dan konsultasi gizi bagi masyarakat. 
- Melakukan pengkajian/penelitian dan riset untuk melihat pengaruh budaya terhadap makanan itu sendiri dengan berbagai implikasi yang terkait didalamnya. 


\section{DAFTAR PUSTAKA}

Gloria, 2018, "Pendekatan Budaya Dapat Meningkatkan Kebiasaan Makan Pangan Lokal”. Diakses Pada 8 Desember 2021, dari https://www.ugm.ac.id/id/berita/15589-pendekatanbudaya-dapat-meningkatkan-kebiasaan-makan-pangan-lokal.

Ibrahim dkk.(2021). "Hubungan Sosial Budaya Dengan Kejadian Stunting PadaBalita Usia 24-59 Bulan Di Desa Bone-Bone Kecamatan Baraka Kabupaten Enrekang Tahun 2020” $1(1), 22-23$.

Ken Fitriani, 2018, “Budaya Pengaruh Sikap Kebiasaan Makan Pangan Lokal”. Diakses Pada 8 Desember 2021, dari https://radioedukasi.kemdikbud.go.id/read/1627/budayapengaruhi-sikap-kebiasaan-makan-pangan-lokal.html.

La Banudi, Imanuddin. (2017). “Sosiologi Dan Antropolodi Gizi”. Panorogo: FORIKES.

Universitas Bakrie, 2013, "Makanan Dalam Konteks Nature Dan Culture”. Diakses Pada 8 Desember 2021, https://www.bakrie.ac.id/berita-itp/artikel-pangan/924-makanan-dalamkonteks-nature-dan-culture. 